\title{
Spis deg frisk
}

I Tidsskriftet nr. 2/1932 beskrives en diett som kunne være gunstig ved mange tilstander - blant annet tuberkulose, migrene, nerve- og sinnslidelser, kronisk obstruksjon, nyrestein. Dietten er «så vidt mulig koksaltfri, eggehvitefattig (ca. 50 gr. daglig), kullhydratfattig, fettrik samt rik på vitaminer og næringsstoffer. Der er servert noget rå grønsaker og rå frukt daglig - også i form av friske pressafter (ca. 1/2 liter av hver sort). Mineralogen - eller det norske minoral - har vært anvendt i en del tilfeller, likeså tran eller eujecor med fosfor». Forfatterne viser hvor effektiv den er i behandlingen av høyt blodtrykk (Tidsskr Nor Lægeforen 1932; 52: 65-74).

\section{«Gerson»-dietens anvendelse. En foreløbig meddelelse fra Midtstuen sanatorium, Holmenkollen.}

Av E. Møinichen og Harald Frøshaug.

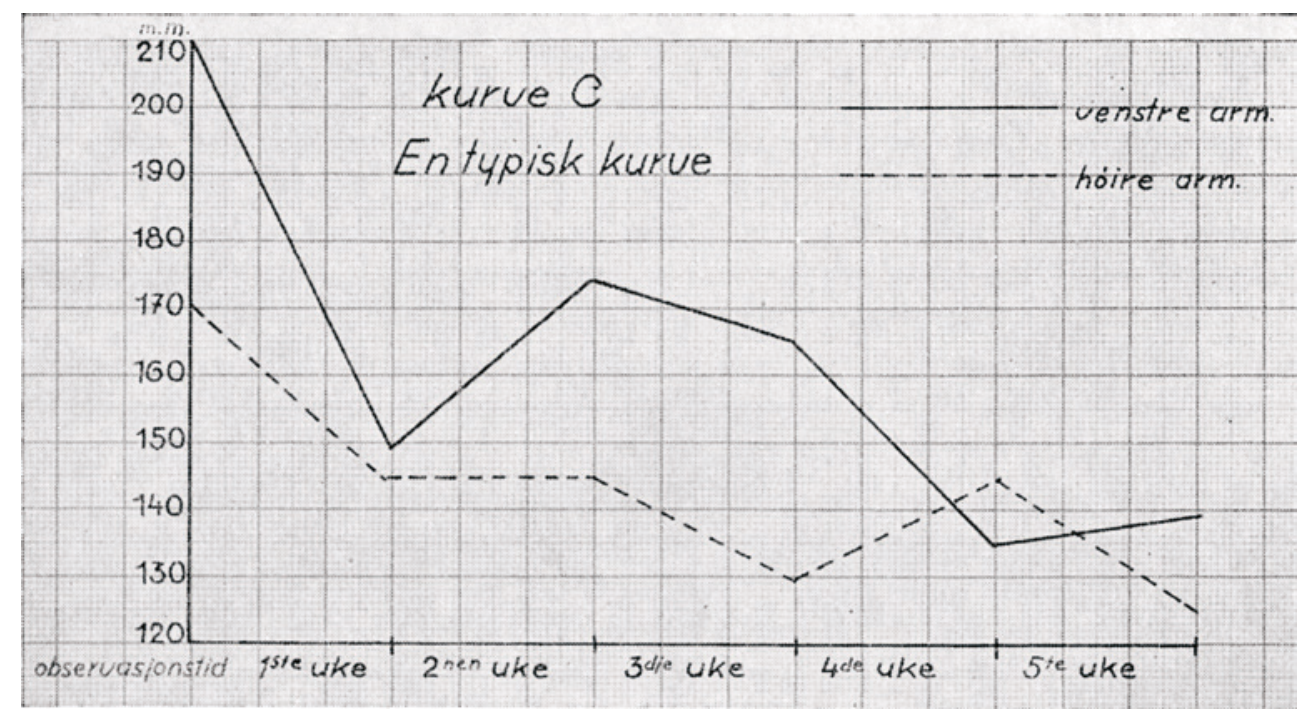

Patienten hadde de siste år følt sig svimmel. Efterat Ge r s o n - d i et var instituert følte hun sig temmelig snart subjektivt bedre. Kurvene viser blodtrykkets forhold under dieten. Man merker sig forskjellen iblodtrykket på høire og venstre arm.

Kurven viser et temmelig typisk forhold av blodtrykket under en Gerson-diet. Først faller trykket temmelig langt ned for så å stige en smule, hvorpå igjen blodtrykksverdiene synker - for å holde sig på et lavt nivå.

Som det vil fremgå av vedføiede kasuistikk, og som det også er søkt illustrert i de opstillede kurver, faller gjerne blodtrykket sterkt den første uke. Derefter kommer gjerne en mindre stigning, så et mindre fall, hvorefter trykket holder sig eller synker langsomt. Nu er jo ikke det noget merkelig, at man kan få blodtrykket til å falle, og tildels temmelig meget. Det kan skje på mange måter, for eksempel ved veneseksjon, ved medikamenter - ofte bare ved ro, ferie, sengeleie, regulert regime og noget innskrenket diet. Men vårt inntrykk er, at Gersondieten virker kraftigere enn de andre metoder. Blodtrykket faller kraftigere og fallet har en tendens til å være varig - iallfall så lenge dieten blir gjennemført og så lenge vi har hatt anledning til å følge patientene. Og det som for oss har vært mest bemerkelsesverdig, er at tross det tildels svære og plutselig fall av blodtrykket har det subjektive befinnende som regel vært helt udmerket. Uttalelser som: «Jeg føler meg nu bedre enn på mangfoldige år», «Føler meg 10 år yngre» 0 . 1. har vært rett hyppige. På bakgrunn av en 25 årig erfaring med fysikalsk og dietetisk behandling av disse tilstander må det vel dog tillegges nogen betydning, at vi ved Midtstuen sanatorium mener å se en vesentlig større nytte av Gersondieten enn av tidligere anvendte behandlingsmåter. I et par tilfeller, hvor der allerede lenge hadde vært anvendt saltfattig diet, medikamentell behandling og fysikalsk behandling, men tilstanden var stasjonær, har institueringen av Gersondiet bragt ytterligere fall av blodtrykket sammen med øket velbefinnende og øket dyktighet (til å spasere eller arbeide). 